\title{
ANALISIS RESTRUKTURISASI DALAM MENINGKATKAN KUALITAS PELAYANAN PUBLIK PADA KANTOR PERTANAHAN KABUPATEN BANDUNG BARAT
}

\author{
Eden Komarudin Soeardi \\ Program Studi Ilmu Adminstrasi Publik Universitas Pasundan \\ eden.komarudian.soeardi@unpas.ac.id
}

\begin{abstract}
Abstrak
Masalah dalam penelitian ini yaitu rendahnya kualitas pelayanan publik pada Kantor Pertanahan Kabupaten Bandung Barat disebabkan belum efektifnya restrukturisasi organisasi. Penelitian ini mengidentifikasi masalah: penelitian ini, sebagai berikut: 1 . Berapa besar pengaruh restrukturisasi organisasi terhadap Kualitas Pelayanan Publik Pada Kantor Pertanahan Kabupaten Bandung Barat. 2. Bagaimana restrukturisasi organisasi mampu meningkatkan kualitas pelayanan publik pada Kantor Pertanahan Kabupaten Bandung Barat. Metode yang digunakan dalam penelitian ini adalah survey deskriptif analisis. Adapun metode yang digunakan dalam penelitian ini adalah metode eksplanatoris, yaitu menyoroti pengaruh antara variabel-variabel penelitian dan menguji hipotesis secara simultan dan secara parsial. Berdasarkan hasil perhitungan koefisien determinasi diperoleh besar pengaruh variable restrukturisasi organisasi terhadap kualitas pelayanan publik pada Kantor Pertanahan Kabupaten Bandung Barat sebesar 71,73\%. Berdasarkan hasil perhitungan tersebut diperoleh hasil bahwa pengaruh variabel restrukturisasi organisasi berpengaruh cukup kuat terhadap kualitas pelayanan publik. Secara Parsial, pengaruh Kompleksitas sebesar 40.16\%. Formalitas sebesar $10.32 \%$ dan Sentralisasi sebesar $21.19 \%$ terhadap kualitas pelayanan publik pada Kantor Pertanahan Kabupaten Bandung Barat.
\end{abstract}

Kata Kunci: Restrukturisasi, Kualitas, Pelayanan, Pertanahan

\section{Pendahuluan}

Restrukturisasi merupakan tindakan untuk merubah struktur dengan menanta kembali atau menata ulang manajemen organisasi yang diorentasikan mengefektifkan organisasi sesuai dengan tuntutan zaman dan kebutuhan masyarakat yang adaptif dengan dinamika perkembangan lingkungan, disamping memiliki tujuan untuk memajukan organisasi dan memudahkan masyarakat dalam menerima pelayanan yang diharapkan. Organisasi pemerintah di daerah masih memiliki permasalahan mendasar dalam pelaksanaan fungsi-fungsi manajemen. Simplifikasi dan sinkronisasi kegiatan masih sering mengalami kendala dengan kuatnya kepentingan antar unit atau bidang.

Restrukturisasi organisasi atau kelembagaan mempunyai beberapa tahapan sebelum dilaksanakan, diantaranya terlebih dahulu perlu diterapkan dasar-dasar pertimbangan atau persyaratan yang harus dipenuhi, agar dapat ditentukan perubahanperubahan apa saja yang diperlukan, dan pegawai mana yang berhak untuk menggantikan kekosongan jabatan atau kelangsungan dalam jabatan tersebut maupun melaksanakan prinsip "the right man in the right place" atau orang yang tepat pada suatu tempat yang tepat. Dengan demikian restrukturisasi yang dijalankan organisasi agar dapat 
dilakukan secara lebih efektif dan efisien. Adanya restrukturisasi, pegawai merasa dirinya dirangsang dan termotivasi untuk berprestasi lebih baik sehingga mereka mempunyai efektivitas yang tinggi sesuai dengan yang diharapkan organisasi. Dengan demikian restrukturisasi organisasi akan memotivasi pegawai dalam melaksanakan pekerjaannya. Hal ini sebagai perwujudan perhatian organisasi terhadap kebutuhan moril dan material dalam diri pegawainya.

Hasil evaluasi kelembagaan yang dilakukan oleh Tim Kementerian Pendayagunaan Aparatur Negara dan Departemen Dalam Negeri, ditemukan fakta adanya kecenderungan untuk membentuk organisasi perangkat daerah yang terlalu besar dan kurang didasarkan pada kebutuhan nyata daerah yang bersangkutan. Berbagai pertimbangan yang digunakan dalam pengambilan keputusan dalam penataan kelembagaan seringkali cenderung lebih bernuansa politik daripada pertimbangan rasional objektif, efisiensi dan efektivitas.

Pengguna atau pelanggan yang dimaksudkan di sini adalah warga negara yang membutuhkan pelayanan publik. Berbagai faktor yang mempengaruhi kualitas pelayanan publik, faktor manusia dan sistem merupakan faktor yang sangat menentukan. Dengan demikian, untuk meningkatkan kualitas pelayanan kepada masyarakat, maka pemberdayaan terhadap para pelaku birokrasi ke arah penciptaan profesionalisme pegawai menjadi sangat menentukan.

Salah satu kendala yang dihadapi adalah ketidaksiapan sejumlah daerah dalam menata dan menyusun kembali struktur organisasi yang disesuaikan dengan tuntutan perubahan serta perangkat daerah yang disesuaikan dengan aturan yang telah dikeluarkan. Hal ini disebabkan oleh keterbatasan aparatur pemerintah di daerah terhadap perubahan paradigma penyelenggaraan pelayanan di daerah, termasuk batasanbatasan yang ditetapkan dalam Peraturan Presiden No. 10 Tahun 2006 tentang Susunan Organisasi Badan Pertanahan Nasional.

Badan Pertanahan Nasional adalah sebuah Lembaga Pemerintah Non Departemen yang dibentuk pada tanggal 19 Juli tahun 1988 berdasarkan Keputusan Presiden Republik Indonesia Nomor 26 tahun 1988. Badan ini merupakan peningkatan dari Direktorat Jenderal Agraria Departemen Dalam Negeri. Sedangkan Kantor Pertanahan adalah unit kerja Badan Pertanahan Nasional di Wilayah Kabupaten/Kota yang melakukan pendaftaran hak atas tanah dan pemeliharaan daftar umum pendaftaran tanah.

Keputusan Presiden No. 26 Tahun 1988 tentang Badan Pertanahan Nasional, bertujuan agar organisasi Direktorat Jenderal Agraria Departemen Dalam Negeri ditingkatkan menjadi Badan Pertanahan Nasional (BPN) yang bertanggung jawab kepada Presiden sedangkan dari segi operasionalnya bertanggung jawab kepada Menteri Sekretaris Negara.

Pada perkembangannya dengan Peraturan Presiden nomor 10 tahun 2006 tentang Badan Pertanahan Nasional, dimana Badan Pertanahan Nasional adalah Lembaga Pemerintah Non Departemen yang berada di bawah dan bertanggung jawab kepada Presiden dan dipimpin oleh Kepala. Badan Pertanahan Nasional mempunyai tugas melaksanakan tugas pemerintahan di bidang pertanahan secara nasional, regional dan sektoral.

Tidak optimalnya kualitas pelaayanan publik pada Kantor Pertanahan Kabupaten Bandung Barat 
diketahui melalui beberapa indikatorindikator sebagai berikut:

1. Reliability pelayanan publik rendah. Contoh : Sisa pekerjaan untuk pelayanan pemeriksaan pertanahan yang dilakukan oleh Seksi Survei, pengukuran dan pemetaan mengalami penambahan. Hal ini dapat dilihat berdasarkan laporan pelayanan pertanahan pada tahun 2008 hanya memiliki sisa 23 kasus yang belum terselesaikan tetapi pada akhir tahun 2009 bertambah menjadi 153 kasus yang belum terselesaikan. Hal ini disebabkan karena jumlah pegawai pada Seksi Survei, pengukuran dan pemetaan sangat kurang, dibandingkan dengan luas wilayah dan kondisi infrastruktur yang tidak memadai sehingga pelayanan yang telah dijanjikan kepada masyarakat terhadap pelayanan yang tepat dan benar tidak tercapai.

2. Responsiveness pelayanan publik rendah. Contoh : Masih lambatnya Seksi Hak Tanah dan Pendaftaran Tanah dalam upaya memberikan saran dan pertimbangan usulan penetapan hak pengelolaan tanah kepada masyarakat untuk mendaftarkan tanahnya. Dari jumlah bidang tanah seluas 496.700 bidang hanya $15 \%$ saja yang terdaftar. Hal ini disebabkan karena kebutuhan sarana dan prasarana untuk mencapai lokasi wilayah pedalaman yang belum memiliki infrastruktur yang baik, kurang menunjang untuk melaksanakan pendataan dalam.

Berdasarkan indikator masalah tersebut, yang menjadi penyebab kurang optimalnya kualitas pelayanan publik adalah restrukturisasi organisasi.
Problem statement dalam penelitian ini adalah : Kualitas Pelayanan Publik Kantor Pertanahan Kabupaten Bandung Barat rendah. Berpedoman pada problem statement tersebut, dapat diidentifikasikan masalah penelitian ini, sebagai berikut :
1. Berapa besar pengaruh restrukturisasi organisasi terhadap Kantor Pertanahan Kabupaten Bandung Barat. Kualitas Pelayanan Publik Pada
2. Bagaimana restrukturisasi organisasi mampu meningkatkan kualitas pelayanan publik pada Kantor Pertanahan Kabupaten Bandung Barat.
A. Tinjauan
Restrukturisasi Organisasi
tentang
Struktur organisasi bertujuan untuk menjalankan fungsi-fungsi organisasi secara efektif. Tujuan suatu organisasi merupakan landasan untuk menentukan model struktur organisasi yang sesuai, karena melalui struktur organisasi tersebut, berbagai sumber daya baik sumber daya manusia maupun sumber daya material diatur dan dikelompokkan. Adapun pengertian restrukturisasi organisasi menurut Suad Husnan dan Enny Pudjiastuti (2004:101) bahwa "restrukturisasi organisasi merupakan kegiatan untuk merubah struktur organisasi”. Sedangkan pengertian dari restrukturisasi organisasi James C. Van Horne dan John M. Wachowicz, JR., yang diterjemahkan oleh Dewi Fitriasari dan Denny Arnos Kwari (2005:473), bahwa "restrukturisasi diikuti dengan adanya perubahan dalam struktur modal, operasi, atau kepemilikan perusahaan yang merupakan rutinitas usahanya".Dari pengertian tersebut dapat kita ketahui bahwa restrukturisasi organisasi adalah tindakan atau kegiatan merubah struktur perusahaan melalui 
pertimbangan dan untuk tujuan tertentu, dimana semuanya itu harus berdasarkan dengan ketentuan perundang-undangan yang berlaku.

Mintzberg dalam Sedarmayanti (1999:65) juga mengemukakan tentang empat aspek desain atau restrukturisasi beserta parameter-parameternya. Keempat aspek itu adalah :

a. Design of position dengan parameter :

- Job specialization

- Behavior formalization

- Training and indoctrination

b. Design of superstructure dengan parameter :

- Unit grouping

- Unit size

c. Design of lateral linkage dengan parameter :

- Planning and control system

\section{- Liaison device}

d. Design of decision making system dengan parameter :

- ertical and horizontal decentralization.

Aspek-aspek yang perlu diperhatikan dalam pembentukan desain organisasi adalah perancangan posisi, hal ini bertujuan untuk memformulasikan apakah desain struktur organisasi menjadi gemuk atau ramping; perancangan struktur organisasi, hal ini bertujuan untuk mengelompokkan berbagai unit kerja untuk menganalisis berapa besar kebutuhan sumber daya yang harus dilibatkan pada masing-masing unit kerja tersebut; perancangan hubungan antar unit, hal ini ditujukan untuk memformulasikan sistem alur kerja organisasi serta tahapan-tahapannya dalam mencapai tujuan; perancangan sistem pengambilan keputusan, hal ini difokuskan kepada pembagian kewenangan dan tugas kerja.

Berdasarkan pendapat para ahli di atas, dapat dikemukakan bahwa restrukturisasi sebagai upaya mendesain kembali struktur organisasi yang mengarah pada upaya menata ulang seluruh aspek potensial yang dimiliki organisasi, sehingga efisiensi, produktivitas dan kinerja pegawai dapat lebih ditingkatkan. Dalam pengertian luas, menurut Bramantyo Djohanputro (2004 : 33), restrukturisasi dapat dikategorikan ke dalam tiga jenis :

a. Restrukturisasi portofolio/asset merupakan kegiatan penyusunan portofolio perusahaan supaya kinerja perusahaan menjadi semakin baik yang termasuk ke dalam portofolio perusahaan adalah setiap asset, unit bisnis, unit divisi, unit usaha atau SBU (Strategi Business Unit) maupun anak perusahaan.

b. Restrukturisasi model/keuangan adalah penyusunan ulang komposisi perusahaan supaya kinerja keuangan menjadi lebih sehat. Kinerja keuangan dapat dievaluasi berdasarkan laporan laba/rugi, laporan arus kas dan posisi modal perusahaan.

c. Restrukturisasi manajemen / organisasi merupakan penyusunan ulang komposisi manajemen, struktur organisasi, pembagian kerja, sistem operasional dll, yang berkaitan dengan masalah manajerial dan keorganisasian. Dalam hal ini restrukturisasi manajemen / organisasi perbaikan kinerja diperoleh melalui beberapa cara antara lain dengan pelaksanaan yang lebih efisien dan efektif, pembagian wewenang yang lebih baik sehingga keputusan tidak berbelit-belit dan kompetensi staf yang lebih mampu menjawab permasalahan di setiap unit kerja.

Restrukturisasi pada dasarnya 
melakukan perubahan dan perbaikan terhadap organisasi agar lebih sehat dan mampu bersaing secara global. Permasalahan yang terjadi pada organisasi merupakan suatu kendala dan tantangan yang harus diperbaiki agar kinerja organisasi dapat meningkat. Analisis organisasi dilakukan untuk mengetahui kelemahan yang terjadi pada organisasi, meliputi kinerja perusahaan, kinerja keuangan dan kinerja manajemen. Perubahan didasarkan pada evaluasi sejauhmana kinerja organisasi tersebut sudah berjalan secara baik, sehingga dapat diketahui jenis perubahan yang bagaimana yang paling tepat.

\section{B. Lingkup Kualitas Pelayanan Publik}

Roger (1995:157) mendefinisikan kualitas sebagai "kecocokan penggunaan yang artinya barang atau jasa dalam rangka memenuhi kebutuhan pelanggan atau pelanggan". Sedangkan menurut Crosby dalam Nasution (2004:41) kualitas adalah "conformance to requirement", yaitu sesuai dengan yang disyaratkan atau distandarkan, bila suatu produk memiliki kualitas apabila sesuai dengan standar kualitas yang telah ditentukan dengan meliputi bahan baku, proses produksi, dan produk jadi.

\section{Cravens}

(1998:23)

mengungkapkan pengertian pelayanan yaitu upaya dalam memenuhi permohonan untuk menspesifikasikan produk-produk seperti data kinerja, permohonan untuk rincian, pemrosesan pesanan pembelian, penyelidikan status pesanan, dan layanan garansi. Kualitas pelayanan publik merupakan hasil interaksi dari berbagai aspek, yakni sistem pelayanan, sumber daya manusia pemberi pelayanan, strategi, dan customer, seperti nampak pada gambar berikut.
Gambar Segitiga Pelayanan Publik

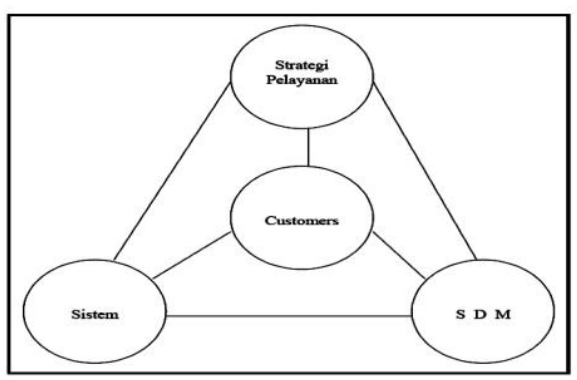

Sumber : Albrecht and Zemke

Sistem pelayanan publik yang baik akan menghasilkan kualitas pelayanan yang baik pula. Suatu sistem yang baik akan memberikan prosedur pelayanan yang terstandar dan memberikan mekanisme kontrol di dalam dirinya (built in control). Dengan demikian segala bentuk penyimpangan yang terjadi akan mudah diketahui. Sistem pelayanan harus sesuai dengan kebutuhan customers. Ini berarti organsiasi harus mampu merespons kebutuhan dan keinginan customers dengan menyediakan sistem pelayanan dan strategi yang tepat.

Tinggi rendahnya kualitas pelayanan publik, perlu diperhatikan adanya keseimbangan antara : Bagian antar pribadi yang melaksanakan (Inter Personal Component); Bagian proses dan lingkungan yang mempengaruhi (Process and Environment Component); Bagian profesional dan teknik yang dipergunakan (Professional and Technical Component). Hal tersebut dapat digambarkan sebagai berikut :

Gambar Segitiga Keseimbangan dalam Kualitas Pelayanan

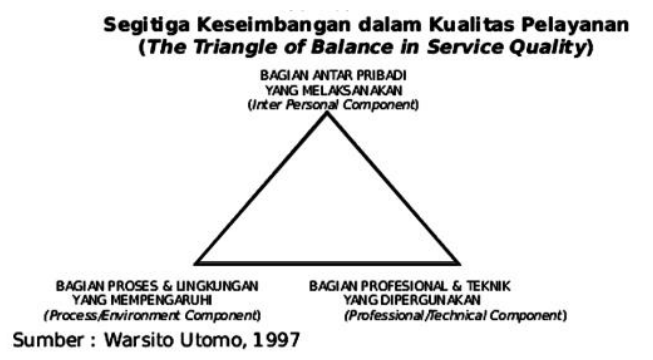


Zeithaml

(1990:63)

mengemukakan dalam mendukung hal tersebut, ada 10 (sepuluh) dimensi yang harus diperhatikan dalam melihat tolok ukur kualitas pelayanan publik, yaitu sebagai berikut :

1. Tangible, terdiri atas fasilitas fisik, peralatan, personil dan komunikasi;

2. Reliable, terdiri dari kemampuan unit pelayanan dalam menciptakan pelayanan yang dijanjikan dengan tepat;

3. Responsiveness, kemauan untuk membantu konsumen bertanggung jawab terhadap kualitas pelayanan yang diberikan;

4. Competence, tuntutan yang dimilikinya, pengetahuan dan ketrampilan yang baik oleh aparatur dalam memberikan pelayanan;

5. Courtesy, sikap atau perilaku ramah, bersahabat, tanggap terhadap keinginan konsumen serta mau melakukan kontak atau hubungan pribadi;

6. Credibility, sikap jujur dalam setiap upaya untuk menarik kepercayaan masyarakat;

7. Security, jasa pelayanan yang diberikan harus bebas dari berbagai bahaya dan resiko;

8. Access, terdapat kemudahan untuk mengadakan kontak dan pendekatan;

9. Communication, kemauan pemberi pelayanan untuk mendengarkan suara, keinginan atau aspirasi pelanggan, sekaligus kesediaan untuk selalu menyampaikan informasi baru kepada masyarakat;
10. Understanding the customer, melakukan segala usaha untuk mengetahui kebutuhan pelanggan

Semakin baik faktor struktur organisasi, kemampuan aparat dan sistem pelayanan maka kualitas pelayanan publik akan semakin baik pula dan semakin dapat memuaskan masyarakat sebagai pengguna hasil pelayanan. Hal ini dapat dilihat pada gambar sebagai berikut :

Gambar Konsep faktor yang

Mempengaruhi Kualitas Pelayanan Publik

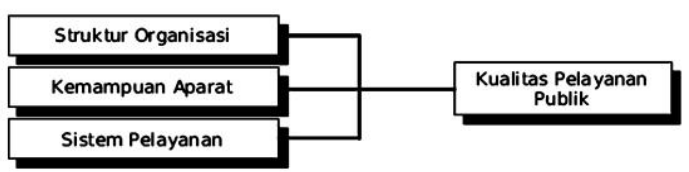

Sumber : Peneliti 201I

\section{Kerangka Pemikiran}

Restrukturisasi sebagai upaya mendesain kembali struktur organisasi yang mengarah pada upaya menata ulang seluruh aspek potensial yang dimiliki organisasi, sehingga efisiensi, produktivitas dan kinerja pegawai dapat lebih ditingkatkan. Proses restrukturisasi adalah terjadinya perubahan organisasi yang ditujukan untuk mengantisipasi kondisi eksternal dengan membenahi kondisi internalnya, oleh karena itu perlu adanya organisasi yang lebih fleksibel. Robbins dalam Pujaatmaka dan Molan (1994:89) mengemukakan bahwa unsur-unsur yang harus dipertimbangkan dalam merestrukturisasi organisasi adalah sebagai berikut :

1) Kompleksitas. Kompleksitas merujuk pada tingkat diferensiasi yang ada di dalam sebuah organisasi. Diferensiasi horizontal mempertimbangkan tingkat pemisahan horizontal diantara unit-unit. Diferensiasi vertikal 
merujuk pada kedalaman hierarki organisasi. Direfensiasi spasial meliputi tingkat sejauhmana lokasi fasilitas dan para pegawai organisasi tersebut secara geografis. Peningkatan pada salah satu faktor tersebut akan meningkatkan kompleksitas sebuah organisasi.

2) Formalitas. Formalisasi merujuk pada tingkat sejauhmana pekerjaan di dalam organisasi itu distandarisasikan. Jika sebuah pekerjaan sangat diformalisasikan, maka pemegang pekerjaan itu hanya mempunyai sedikit kebebasan mengenai apa yang harus dikerjakan, bilamana mengerjakannya, dan bagaimana ia harus melakukannya.

3) Sentralisasi merujuk kepada tingkat dimana pengambilan keputusan dikonsentrasikan pada suatu titik tunggal di dalam organisasi. Konsentrasi yang tinggi menyatakan adanya sentralisasi yang tinggi, sedangkan konsentrasi yang rendah menunjukkan sentralisasi yang rendah atau yang disebut desentralisasi. Ada juga kesepakatan bahwa desentralisasi sangat berbeda dari desentralisasi spasial. Sentralisasi memperhatikan penyebaran kekuasaan untuk membuat keputusan dalam organisasi, bukan penyebaran secara geografis pada pembangunan rumah.

Pengubahan struktur organisasi menyangkut modifikasi dan pengaturan kembali berbagai system internal, seperti hubungan-hubungan tanggung jawab wewenang, sistem komunikasi, aliran kerja, ukuran dan komposisi kelompok kerja atau hierarki manajerial. Pengubahan teknologi organisasi berarti pengubahan atau modifikasi faktor-faktor seperti peralatan, proses teknik, teknik-teknik riset, atau sistem produksi yang mencakup layout, metode dan prosedur. Pengubahan orang-orang organisasi mencakup pengubahan kebijaksanaan dan prosedur penarikan serta seleksi, kegiatan-kegiatan latihan dan pengembangan, sistem balas jasa dan ketrampilan-ketrampilan kepemimpinan dan komunikasi manajerial sikap, kepercayaan, peranan atau karakteristikkarakteristik karyawan lainnya. Dalam kaitan ini struktur organisasi ditata kembali agar menjadi organisasi yang "open system" yaitu organisasi yang responsif dan adaptif terhadap perubahan, mampu menunjang kelancaran operasional, memiliki fleksibilitas tinggi, mampu melaksanakan pengendalian dan meningkatkan akuntabilitas.

Berkaitan dengan kualitas pelayanan publik, Nasution (2004:47) mengemukakan definisi kualitas pelayanan sebagai "tingkat keunggulan yang diharapkan dan pengendalian atas tingkat keunggulan tersebut untuk memenuhi keinginan pelanggan". Selanjutnya kualitas layanan publik menurut Fitzsimmons dalam Sedarmayanti (2000: 204) dapat dilihat pada lima dimensi yaitu:

1) Reliability, kemampuan untuk memberikan secara tepat dan benar, jenis pelayanan yang telah dijanjikan kepada konsumen/pelanggan;

2) Responsiveness, kesadaran atau keinginan untuk membantu konsumen dan memberikan pelayanan yang cepat;

3) Assurance, pengetahuan atau wawasan, kesopanan, santun, kepercayaan diri dari pemberi layanan, serta respek terhadap konsumen; 
4) Empathy, kemauan pemberi layanan untuk melakukan pendekatan, memberi perlindungan, serta berusaha untuk mengetahui keinginan dan kebutuhan konsumen;

5) Tangibles, penampilan para pegawai dan fasilitas fisik lainnya seperti peralatan atau perlengkapan yang menunjang pelayanan.

Organisasi publik pada masa yang akan datang tidak dapat berpegang pada proteksi undang-undang terhadap layanan monopoli yang mungkin mengabaikan kualitas. Organisasi pemerintah juga dapat mengalami tekanan yang mungkin akan memberi pengaruh yang signifikan terhadap eksistensi organisasi jika terbukti mengabaikan kualitas. Karena itu, filosofi organisasi dengan menjadikan kualitas sebagai "jalan hidup" merupakan harapan baik untuk publik yang dilayaninya maupun bagi kelangsungan organisasi itu sendiri.

Hubungan antara restrukturisasi organisasi dan kualitas pelayanan publik sebagaimana dikemukakan oleh Sedarmayanti (2000: 71) bahwa:

"Restrukturisasi organisasi dalam arti sangat sempit meliputi aspek kinerja organisasi, kerjasama operasional, sistem dan prosedur kerja serta pendelegasian wewenang dan otonomi. Sedangkan restrukturisasi organisasi dalam arti luas, mencakup seluruh aspek yang dimiliki organisasi yang sangat mempengaruhi produktivitas organisasi, yaitu meliputi : sumber daya manusia, sumber daya keuangan dan sumber daya lainnya termasuk sarana, prasarana dan pelayanan".

Restrukturisasi organisasi merupakan faktor-faktor yang perlu mendapat perhatian dalam rangka meningkatkan kualitas pelayanan publik pada Kantor Pertanahan Kabupaten Bandung Barat. Berdasarkan uraian kerangka pemikiran di atas, maka disusun paradigma pemikiran sebagai berikut:

\section{Gambar Paradigma pemikiran tentang Restrukturisasi Organisasi dan Kualitas Pelayanan Publik}

\begin{tabular}{|c|c|}
\hline \multicolumn{1}{|c|}{ RESTRUKTURISASI } \\
ORGANISASI \\
Robbins dalam Pujaatmaka dan \\
Molan(1994:89-115): \\
1. Kompleksitas \\
2. Formalitas \\
3. Sentralisasi
\end{tabular} \mid $\begin{aligned} & \text { KUALITAS PELAYANAN } \\
& \text { PUBLIK } \\
& \text { Fitzsimmons dalam } \\
& \text { Sedarmayanti (2000: 204) } \\
& \text { 1. Reliability } \\
& \text { 2. Responsiveness } \\
& \text { 3. Assurance } \\
& \text { 4. Empathy } \\
& \text { 5. Tangibles } \\
& \end{aligned}$

\section{Hipotesis}

Berdasarkan Kajian Pustaka, Kerangka pemikiran di atas, hipotesis yang diajukan penulis dalam penelitian ini adalah :
1. Restrukturisasi organisasi besar pengaruhnya terhadap kualitas pelayanan publik pada Kantor Pertanahan Kabupaten Bandung Barat. 
2. Restrukturisasi organisasi melalui unsur kompleksitas, unsur formalitas dan unsur sentralistik besar pengaruhnya terhadap kualitas pelayanan publik pada Kantor Pertanahan Kabupaten Bandung Barat.

\section{Metode Penelitian}

Metode yang digunakan dalam penelitian ini adalah survey deskriptif analisis. Adapun metode yang digunakan dalam penelitian ini adalah metode eksplanatoris, yaitu menyoroti pengaruh antara variabel-variabel penelitian dan menguji hipotesis yang telah dirumuskan sebelumnya.

\section{Hasil Penelitian dan Pembahasan}

Penelitian ini mengambil data dari sejumlah bagian atau seksi pada lembaga atau kantor Pertanahan Kabupaten Bandung Barat. dengan total responden yang dijadikan sumber untuk penelitian ini sebanyak 61 (enam puluh satu orang). Data yang peneliti peroleh dari responden adalah data dalam bentuk ordinal sehingga untuk keperluan penelitian, peneliti ubah data tersebut menjadi data dalam bentuk interval melalui method of successive interval (MSI). Data ordinal tersebut kemudian peneliti uji dengan uji validitas data dan uji reliabilitas data sehingga diperoleh data yang benarbenar sesuai untuk hasil penelitian ini.

\section{A. Pengaruh Restrukturisasi Organisasi terhadap Kualitas Pelayanan Publik pada Kantor Pertanahan Kabupaten Bandung Barat}

Adapun proses perhitungannya, peneliti gunakan software SPSS versi 12 dan software Microsoft excel dengan langkah-langkah sebagai berikut:

\section{i. Perhitungan Matriks korelasi}

Perhitungan matriks korelasi merupakan langkah awal dari perhitungan analisis jalur. Matriks korelasi ini berisi tentang korelasi atau hubungan antara unsurunsur yang ada dalam variable restrukturisasi organisasi dengan variable kualitas pelayanan publik. Korelasi tersebut ditampilkan dalam bentuk matriks atau table. Misalnya korelasi antara $\mathrm{x} 1$ dengan $\mathrm{x} 2$, pada table tersebut ditampilkan pada perpotongan secara horizontal variable $\mathrm{x} 1$ dan secara vertikal dengan x2. Adapun secara jelasnya dapat dilihat pada table matriks korelasi di bawah ini.

\begin{tabular}{|l|l|l|l|l|l|}
\hline \multirow{4}{*}{ Corr } & & x1 & x2 & x3 & $Y$ \\
\cline { 2 - 6 } & $\mathrm{x} 1$ & 1 & 0.345799 & 0.597119 & 0.781003 \\
\cline { 2 - 6 } & $\mathrm{x} 2$ & 0.345799 & 1 & 0.200126 & 0.463781 \\
\cline { 2 - 6 } & $\mathrm{x} 3$ & 0.597119 & 0.192516 & 1 & 0.667531 \\
\cline { 2 - 6 } & $\mathrm{y}$ & 0.781003 & 0.464563 & 0.667531 & 1 \\
\hline
\end{tabular}

Sumber: Perhitungan Matriks korelasi Ms Excel, 2011

Berdasarkan table di atas diperoleh data sebagai berikut:

$$
\begin{aligned}
\operatorname{rx}_{1} \mathrm{x}_{2} & =0.345799 \\
\mathrm{rx}_{1} \mathrm{x}_{3} & =0.597119 \\
\operatorname{rx}_{1} \mathrm{Y} & =0.781003
\end{aligned}
$$$$
\mathrm{rx} 2 \times 3=0.192516
$$

$$
\begin{aligned}
\operatorname{rx} 2 \mathrm{Y} & =0.464563 \\
\operatorname{rx} 3 \mathrm{Y} & =0.667531
\end{aligned}
$$

\section{ii. Perhitungan Matriks Invers}


Perhitungan matriks invers adalah merupakan tahap kedua dari proses perhitungan analisa jalur (path analysis).
Perhitungan mempergunakan software Microsof Excel. Adapun output perhitungan dapat dilihat pada tabulasi di bawah ini.

Tabel Inverse of Correlation Matrix

\begin{tabular}{|l|l|l|l|}
\hline & $\mathrm{x} 1$ & $\mathrm{x} 2$ & $\mathrm{x} 3$ \\
\hline $\mathrm{x} 1$ & 1.697459 & -0.40755 & -0.93202 \\
\hline $\mathrm{x} 2$ & -0.39953 & 1.135996 & 0.011223 \\
\hline $\mathrm{x} 3$ & -0.93667 & 0.024659 & 1.554368 \\
\hline
\end{tabular}

Sumber: Perhitungan Ms Excel, 2011

Berdasarkan data tersebut diperoleh hasil sebagai berikut:
CR11 $=1.697459$
$\mathrm{CR} 12=-0.40755$
$\mathrm{CR} 13=-0.93202$
$\mathrm{CR} 21=-0.39953$
$\mathrm{CR} 22=1.135996$
$\mathrm{CR} 23=0.024659$
CR31 =-0.93667
CR32 $=0.024659$
$\mathrm{CR} 33=1.554368$

iii. Perhitungan Koefisien Jalur

Koefisien jalur adalah sebuah angka numeric yang menghubungkan variable bebas ke variable terikat. Nilai koefisien ini menghubungkan masing-masing
PYX1 = rYX1.CR11 + rYX2.CR12 + rYX3.CR13
PYX2 = rYX1.CR21 + rYX2.CR22 + rYX3.CR23
PYX3 = rYX1.CR31 + rYX2.CR32 + rYX3.CR33

Adapun hasil proses perhitungan di atas adalah:

Pyx $1=0.514233$ pyx $2=0.223201$ pyx $3=0.317503$

\section{iv. Perhitungan \\ Determinasi}

Koefisien determinasi adalah besar pengaruh variable bebas terhadap variable terikat yang dalam penelitian ini adalah besarnya pengaruh variable restrukturisasi organisasi terhadap kualitas pelayanan publik secara keseluruhan. Perhitungan koefisien determinasi mempergunakan rumus berikut:

$$
\begin{gathered}
\mathrm{R}^{2} \mathrm{Y}(\mathrm{x} 1 . \mathrm{x} 2 . \mathrm{x} 3)=\text { pyx1.ryx } 1+ \\
\text { pyx2.ryx2+pyx3.ryx3 } \\
\mathrm{R}^{2} \mathrm{Y}(\mathrm{x} 1 . \mathrm{x} 2 . \mathrm{x} 3)=0.514233 \mathrm{x} \\
0.781003+0.223201 \times 0.464563+ \\
0.317503 \times 0.667531 \\
\mathrm{R}^{2} \mathrm{Y}(\mathrm{x} 1 . \mathrm{x} 2 . \mathrm{x} 3)=0.717252
\end{gathered}
$$

Berdasarkan hasil perhitungan koefisien determinasi diperoleh besar pengaruh variable restrukturisasi organisasi terhadap kualitas pelayanan publik pada Kantor Pertanahan Kabupaten Bandung Barat sebesar 71,73\%. Berdasarkan hasil perhitungan tersebut diperoleh hasil bahwa pengaruh variabel restrukturisasi organisasi berpengaruh cukup kuat terhadap kualitas pelayanan publik, maka apabila dituangkan dalam model diagram analisis jalur akan diperoleh model hasil pengujian diagram jalur antara variable $\mathrm{x}$ dan variable $\mathrm{y}$ sebagai berikut: 
DECISION: Jurnal Administrasi Publik

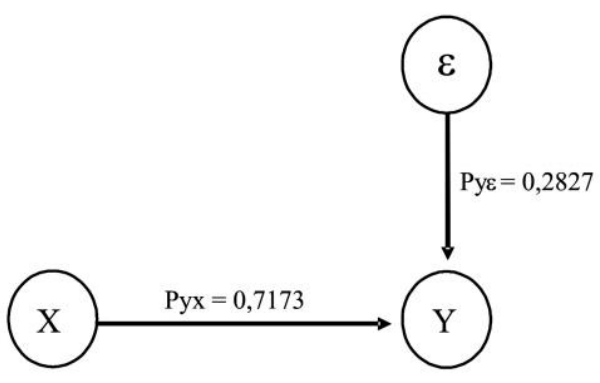

Gambar Hasil pengujian pengaruh langsung variable $\mathrm{X}$ terhadap $\mathrm{Y}$

v. Perhitungan besar pengaruh secara parsial

○ Pengaruh $\mathrm{X}_{1}$ terhadap $\mathrm{Y}$

- Pengaruh langsung pyx $1^{2}$ $=(0.514233)^{2}$

$$
=0.264438
$$

- Pengaruh $\mathrm{x} 1$ terhadap y melalui

(pyx1).(rx1x2).(pyx2) :

$0.514233 \times 0.345799 \times$

0.223201

$$
=0.03969
$$

- Pengaruh x1 terhadap y melalui (pyx1).(rx1x3).(p yx3) :

$0.514233 \times 0.597119 \times$ 0.317503

$$
=0.097492
$$

Total pengaruh $\mathrm{x} 1$

terhadap y

$=40,16 \%$

○ Pengaruh $\mathrm{X}_{\mathbf{2}}$ terhadap $\mathrm{Y}$

- Pengaruh langsung pyx $2^{2}$ $=(0.223201)^{2}$

$$
=0.049819
$$

Vol. 1 No. 1, Maret 2019

- Pengaruh $\mathrm{x} 2$ terhadap $\mathrm{y}$ melalui $\mathrm{x} 1$ (pyx1).(rx1x2).(p yx2) :

$0.514233 \times 345799 \times$ 0.223201

$$
=0.03969
$$

- Pengaruh x2 terhadap y melalui yx3) : (pyx2).(rx2x3).(p

$0.223201 \times 0.192516 \times$ 0.317503

$$
\mathbf{0 . 0 1 3 6 4 3}
$$

Total pengaruh $\mathrm{x} 2$ terhadap y

$=10,32 \%$

- Pengaruh X3 terhadap Y

- Pengaruh langsung pyx $3^{2}$ $=0.317503^{2}$

$$
=0.100808
$$

- Pengaruh x3 terhadap y melalui $\mathrm{x} 1$ (pyx 1).(rx1x3).(p yx3) :

$0.514233 \times 0.597119 \times$

0.223704

$$
\text { = 0,097492 }
$$

- Pengaruh x3 terhadap y melalui

$$
\text { yx3) : }
$$

$$
\text { (pyx2).(rx2x3).(p }
$$

$$
0.223201 \mathrm{x} \quad 0.192516 \mathrm{x}
$$

0.223704

$$
=\mathbf{0 , 0 1 3 6 4 3}
$$

Total pengaruh $\mathrm{x} 3$

terhadap y

$$
\mathbf{2} 1, \mathbf{1 9} \%
$$

Tabel

Hasil Perhitungan Besar Pengaruh Masing-masing Unsur

Variabel Restrukturisasi Organisasi terhadap Kualitas Pelayanan Publik

\begin{tabular}{|l|l|lll|l|}
\hline $\begin{array}{l}\text { Pengaruh } \\
\text { variabel }\end{array}$ & $\begin{array}{l}\text { Langsung } \\
(\%)\end{array}$ & $\begin{array}{l}\text { Tidak langsung } \\
(\%)\end{array}$ & $\begin{array}{l}\text { Total } \\
(\%)\end{array}$ \\
\hline $\mathrm{X}_{1}$ terhadap Y & 26,44 & $\begin{array}{l}3,97+ \\
13,72\end{array}$ & $9,75=$ & 40,16 \\
\hline
\end{tabular}


DECISION: Jurnal Administrasi Publik

Vol. 1 No. 1, Maret 2019

\begin{tabular}{|l|l|l|l|}
\hline $\mathrm{X}_{2}$ terhadap $\mathrm{Y}$ & 4,98 & $\begin{array}{l}3,97+1,37 \\
5,33\end{array}$ & 10,32 \\
\hline $\mathrm{X}_{3}$ terhadap $\mathrm{Y}$ & 10,08 & $\begin{array}{l}9,75+1,36= \\
11,11\end{array}$ & 21,19 \\
\hline
\end{tabular}

Sumber : Pengolahan data, 2011

Berdasarkan hasil perhitungan tersebut diperoleh hasil bahwa pengaruh variabel restrukturisasi organisasi melalui unsur kompleksitas, unsur formalitas dan unsur sentralisasi terhadap kualitas pelayanan publik

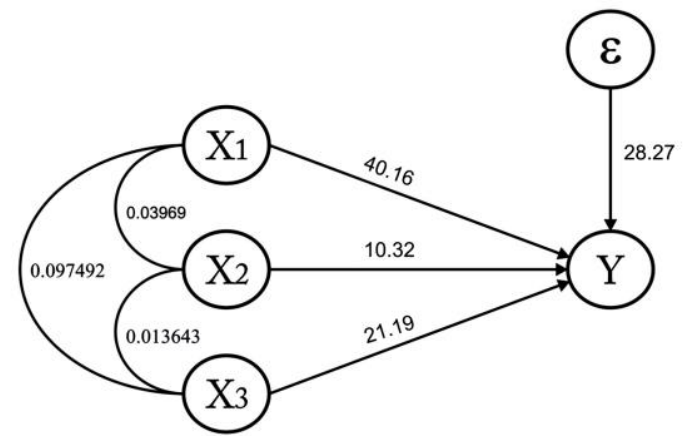

Gambar Pengaruh langsung dan korelasi antara variabel restrukturisasi organisasi terhadap kualitas pelayanan publik

\section{B. Pengujian Hipotesis}

Pengujian hipotesis dimaksudkan untuk mengetahui keberartian koefisien jalur (test of significance) setiap koefisien jalur yang dihitung baik secara simultan atau secara keseluruhan maupun secara sendiri-sendiri atau parsial, serta menguji perbedaan besarnya pengaruh masing-masing variabel bebas terhadap variabel terikat.

\section{a) Pengujian Hipotesis Secara Simultan}

Pengujian hipotesis secara keseluruhan dimaksudkan untuk mengetahui apakah restrukturisasi organisasi berpengaruh terhadap Kualitas Pelayanan Publik ataukah tidak. Pengujian hipotesis secara keseluruhan tidak melihat secara berpengaruh cukup kuat, maka apabila dituangkan dalam model diagram analisa jalur, maka akan diperoleh model hasil pengujian diagram jalur korelasi antara variable $\mathrm{X}_{1}, \mathrm{X}_{2}, \mathrm{X}_{3}$ dan variable $\mathrm{Y}$ sebagai berikut:

detail kandungan dimensi-dimensinya. Pengujian ini mempergunakan uji $\mathrm{F}$. Peneliti membandingkan antara $\mathrm{F}$ hasil perhitungan dengan $\mathrm{F}$ hasil dari tabel. Jika $\mathrm{F}$ hasil perhitungan lebih besar dari F hasil dari tabel maka hipotesis 1 (H1) diterima dan jika $\mathrm{F}$ hasil perhitungan lebih kecil dari $\mathrm{F}$ hasil tabel maka $\mathrm{H} 1$ ditolak yang berarti dugaan peneliti tentang pengaruh restrukturisasi organisasi terhadap Kualitas Pelayanan Publik tidak terbukti atau dengan kata lain restrukturisasi organisasi tidak berpengaruh terhadap kualitas laynan publik.

Adapun bentuk hipotesis secara keseluruhan adalah sebagai berikut 
Ho : Restrukturisasi organisasi tidak berpengaruh terhadap Kualitas Pelayanan Publik.

H1 : Restrukturisasi organisasi berpengaruh terhadap Kualitas Pelayanan Publik.

Uji Statistik:

Uji statistik yang digunakan adalah dengan menggunakan uji $\mathrm{F}$ yaitu:

$$
F=\frac{(n-k-1)\left(R^{2} x_{i i}\left(x_{1}, x_{2}, x_{3}\right)\right)}{k\left(1-R^{2} x_{i i}\left(x_{1}, x_{2}, x_{3}\right)\right)}
$$

dengan:

$\mathrm{n}=$ jumlah data atau jumlah responden

$\mathrm{k}=$ derajat kebebasan $=3$ karena terdapat tiga unsur yaitu kompleksitas, formalitas dan sentralisasi.

$$
\left(R^{2}{ }_{i i}\left(x_{11}, x_{2}, x_{3}\right)\right) \quad=\quad \text { koefisien }
$$

determinasi.

Berdasarkan formulasi di atas maka hasilnya adalah:

$$
F=\frac{(61-3-1)(0,71725)}{3(1-0,71725)}
$$

$\mathrm{F}=51,5798$.

Jika dibandingkan dengan nilai Ftabel dengan tingkat kepercayaan 0,05 dan $\mathrm{dk} 1=3$ dan $\mathrm{dk} 2=\mathrm{n}-\mathrm{k}-1$ yaitu $61-3-1$ atau 57, maka diperoleh Ftabel yaitu 2,7664. Jika dibandingkan dengan nilai F hasil perhitungan maka:

Kriteria pengujian: Ho ditolak jika $F_{\text {hitung }}$ lebih besar dari $F_{\text {tabel, dan }}$ Ho diterima jika Fhitung lebih kecil dari $\mathrm{F}$ tabel.

$F_{\text {hitung }}>F_{\text {tabel }}$ yaitu 51,5798 $>2,7664$.

Berdasarkan data tersebut maka diperoleh hasil bahwa restrukturisasi organisasi berpengaruh terhadap kualitas pelayanan publik pada kantor Pertanahan Kabupaten Bandung Barat.

\section{b) Pengujian Hipotesis Secara Parsial}

Pengujian hipotesis secara parsial dimaksudkan untuk mengetahui pengaruh dari tiap-tiap unsur dari unsurunsur restrukturisasi organisasi terhadap kualitas pelayanan publik pada kantor Pertanahan Kabupaten Bandung Barat. Adapun uji hipotesis yang digunakan adalah uji $\mathrm{t}$ dengan formulasi sebagai berikut:

$$
t=\frac{p x i Y}{\sqrt{\frac{\left(1-R^{2} x_{i i}\left(x_{1}, x_{2}, x_{3}\right) C_{i i}\right.}{n-k-1}}}
$$

1. Pengujian Hipotesis Kompleksitas terhadap Kualitas Pelayanan Publik pada Kantor Pertanahan Kabupaten Bandung Barat. Bentuk Hipotesis:

Ho : Kompleksitas tidak berpengaruh terhadap Kualitas Pelayanan Publik

H1 : berpengaruh terhadap Kualitas Pelayanan Publik

Ketentuan Pengujian: diterima

Jika thitung < ttabel maka Ho

Jika thitung > ttabel maka Ho ditolak atau $\mathrm{H} 1$ diterima.

Uji statistik:

$$
\begin{gathered}
t=\frac{0,514233}{\sqrt{\frac{(1-0,71725) 1.697459}{61-3-1}}} \\
t=5,60399
\end{gathered}
$$

Ttabel $(0,05 ; 57)=2,00247$

Berdasarkan perbandingan antara thitung dan ttabel maka diperoleh hasil bahwa ttabel lebih besar dari thitung atau 5,60399>2,0025 sehingga H1 diterima atau kompleksitas berpengaruh terhadap Kualitas Pelayanan Publik pada Kantor Pertanahan Kabupaten Bandung Barat.

2. Pengujian Pengaruh Formalitas terhadap Kualitas Pelayanan Publik pada Kantor Pertanahan Kabupaten Bandung Barat. 
Bentuk Hipotesis:

Ho : Formalitas tidak berpengaruh terhadap Kualitas Pelayanan Publik

H1 : Formalitas berpengaruh terhadap Kualitas Pelayanan Publik

Ketentuan Pengujian: diterima

Jika $t_{\text {hitung }}<t_{\text {tabel }}$ maka Ho

Jika $t_{\text {hitung }}>t_{\text {tabel }}$ maka $\mathrm{H}_{\mathrm{o}}$ ditolak atau $\mathrm{H}_{1}$ diterima.

Uji statistik:

$$
\begin{gathered}
t=\frac{0,223201}{\sqrt{\frac{(1-0,717252) 1135996}{61-3-1}}} \\
t=2,97335
\end{gathered}
$$

Ttabel $(0,05 ; 57)=2,00247$

Berdasarkan perbandingan antara thitung dan ttabel maka diperoleh hasil bahwa $t_{\text {hitung }}$ lebih besar dari $t_{\text {tabel }}$ atau $2,97335>2,0025$ sehingga $\mathrm{H}_{1}$ diterima atau Formalitas berpengaruh terhadap Kualitas Pelayanan Publik pada Kantor Pertanahan Kabupaten Bandung Barat.

3. Pengujian Pengaruh Sentralisasi terhadap Kualitas Pelayanan Publik pada Kantor Pertanahan Kabupaten Bandung Barat.

Bentuk Hipotesis:

Ho :Sentralisasi tidak berpengaruh terhadap Kualitas Pelayanan Publik

H1 :Sentralisasi berpengaruh terhadap Kualitas Pelayanan Publik

Ketentuan Pengujian:

Jika $t_{\text {hitung }}<t_{\text {tabel }}$ maka Ho diterima

Jika $t_{\text {hitung }}>t_{\text {tabel }}$ maka $\mathrm{H}_{\mathrm{o}}$ ditolak atau $\mathrm{H}_{1}$ diterima.

Uji statistik:

$$
\begin{gathered}
t=\frac{0,317503}{\sqrt{\frac{(1-0,717252) 1135996}{61-3-1}}} \\
t=3,61583 \\
t_{\text {tabel }}(0,05 ; 57)=2,00247
\end{gathered}
$$

Berdasarkan perbandingan antara $t_{\text {hitung }}$ dan $t_{\text {tabel }}$ maka diperoleh hasil bahwa $t_{\text {hitung }}$ lebih besar dari $t_{\text {tabel }}$ atau $3,61583>2,00247$ sehingga $\mathrm{H}_{1}$ diterima atau sentralisasi berpengaruh terhadap Kualitas Pelayanan Publik pada Kantor Pertanahan Kabupaten Bandung Barat.

\section{Pembahasan Secara Simultan Pengaruh Restrukturisasi Organisasi Terhadap Kualitas Pelayanan Publik Pada Kantor Pertanahan Kabupaten Bandung Barat}

Berdasarkan hasil pengujian hipotesis tergambar bahwa variabel restrukturisasi organisasi berpengaruh terhadap kualitas pelayanan publik pada kantor Pertanahan Kabupaten Bandung Barat. Berdasarkan hasil perhitungan statistik tergambar bahwa besar pengaruh variabel restrukturisasi organisasi terhadap kualitas pelayanan publik berpengaruh sebesar $71,73 \%$. Berdasarkan hasil pengujian hipotesis dan perhitungan statistik tersebut maka tergambar bahwa pengaruh dari variabel restrukturisasi organisasi berpengaruh terhadap kualitas pelayanan publik pada kantor Pertanahan Kabupaten Bandung Barat berpengaruh kuat. Berdasarkan data tersebut maka restrukturisasi organisasi harus senantiasa diperhitungkan agar organisasi dapat lebih efektif dan efisien dalam memberikan pelayanan yang paripurna terhadap publik atau masyarakat. Pelayanan adalah merupakan target 
akhir yang harus diberikan oleh organisasi dengan dedikasi pegawai yang tinggi. Sehubungan dengan hal tersebut maka para pegawai sebagai front line dalam organisasi harus senantiasa dioptimalkan perannya dan dimaksimumkan segala daya upayanya.

\section{Pembahasan Secara Parsial Pengaruh Restrukturisasi Organisasi Terhadap Kualitas Pelayanan Publik Pada Kantor Pertanahan Kabupaten Bandung Barat}

Pembahasan secara parsial membahas tentang pengaruh pengaruh dari tiap unsur dari variabel restrukturisasi organisasi terhadap kualitas pelayanan publik pada Kantor Pertanahan Kabupaten Bandung Barat. Sebagai berikut:

\section{i. Pengaruh unsur \\ Kompleksitas}

Berdasarkan hasil pengujian hipotesis tergambar bahwa unsur kompleksitas berpengaruh terhadap kualitas pelayanan publik pada Kantor Pertanahan Kabupaten Bandung Barat. Berdasarkan hasil perhitungan statistik yang peneliti lakukan dengan mempergunakan software pengolah angka Ms Excel diperoleh besar pengaruhnya sebesar $40,16 \%$. Berdasarkan data tersebut maka peneliti menilai bahwa besar pengaruh dari unsur kompleksitas terhadap kualitas pelayanan publik cukup signifikan artinya bahwa unsur kompleksitas memberikan sumbangsih dalam meningkatkan kualitas pelayanan publik pada Kantor Pertanahan Kabupaten Bandung Barat. Berdasarkan hal tersebut maka unsur kompleksitas harus mendapatkan perhatian dari organisasi.

Kompleksitas organisasi atau kompleksitas yang ada di dalam organisasi merupakan dinamika yang ada di dalam setiap gerak langkah organisasi dalam mewujudkan visi dan misinya. Organisasi yang semakin kompleks adalah organisasi yang dinamis. Hal ini berbeda dengan organisasi yang sederhana. Semakin kompleks organisasi maka akan semakin kompleks pula penataannya, permasalahannya dan tantangannya karena organisasi yang bersangkutan menuju pada kondisi maturity atau tingkat posisi matang. Tentu saja untuk menuju ke arah sana, maka berbagai peran yang harus dimainkan harus dijalankan secara optimal baik peran yang harus dimainkan oleh pegawai maupun peran yang harus dimainkan oleh pimpinan.

Para pegawai sebagai front line adalah merupakan garda terdepan di dalam organisasi guna mewujudkan visi dan misi organisasi dalam tataran teknis sehingga berbagai hal yang berkaitan dengan peran para pegawai seperti kelengkapan sarana dan prasarananya harus dipenuhi agar para pegawai semakin mudah dalam menjalankan tugas-tugasnya. Hal yang perlu diperhatikan oleh pimpinan adalah mengelola organisasi dengan tingkat pengelolaan yang profesional sehingga dengan demikian maka organisasi akan semakin maju dan berkembang.

\section{ii. Pengaruh Unsur Formalitas}

Hasil pengujian hipotesis tergambar bahwa unsur formalitas berpengaruh terhadap kualitas pelayanan publik di Kantor Pertanahan Kabupaten Bandung Barat. Berdasarkan hasil perhitungan statistik diperoleh gambaran bahwa besar pengaruh unsur formalitas ini adalah sebesar 10,32\%. Berdasarkan data tersebut maka peneliti berpandangan bahwa unsur formalitas 
memberikan pengaruh yang signifikan terhadap peningkatan kualitas pelayanan publik yang diberikan oleh para pegawai dan organisasi secara keseluruhan. Unsur formalitas harus mendapatkan perhatian walaupun besar pengaruhnya relatif kecil dibandingkan dengan unsur yang lainnya. Hal ini disebabkan karena disamping unsur formalitas, unsur yang lainnya yaitu non formal mendapat perhatian juga disamping unsur formal. Hubungan yang dibangun dengan sesama pegawai ataupun dengan pimpinan bisa dilakukan secara formal maupun non formal. Unsur formal tentu harus dikedepankan karena organisasi Pertanahan adalah organisasi publik yang mengurus hal-hal formal.

Sementara hasil wawancara diperoleh keterangan bahwa dalam rangka meningkatkan kualitas pelayanan publik pada Kantor Pertanahan Kabupaten Bandung Barat, telah memberikan kesempatan kepada para pegawai untuk mengembangkan potensi dirinya, baik melalui pemberian kewenangan pegawai dalam melaksanakan tugasnya dan memberikan tanggung jawab maupun memberikan keseimbangn antara beban dan tanggung jawab kepada karyawan secara berkala dan terprogram. Hal tersebut dimaksudkan agar pegawai dapat menyesuaikan dirinya dalam melaksanakan tugas yang dibebankan kepadanya.

Berdasarkan hasil penelitian yang peneliti lakukan diperoleh gambaran bahwa unsur formal di dalam organisasi sudah dilaksanakan dan unsur formalitas ini harus mendapatkan perhatian agar para pegawai dapat menjalankan tugasnya dengan optimal.

\section{iii. Pengaruh Unsur Sentralisasi}

Berdasarkan hasil pengujian hipotesis tergambar bahwa unsur sentralisasi memberikan pengaruh terhadap peningkatan kualitas pelayanan publik yang harus diberikan kepada masyarakat oleh Kantor Pertanahan Kabupaten Bandung Barat. Berdasarkan hasil perhitungan statistik diperoleh gambaran bahwa besar pengaruh unsur sentralisasi ini adalah sebesar $21,19 \%$. Berdasarkan data tersebut maka peneliti berpandangan bahwa unsur sentralisasi memberikan pengaruh yang signifikan terhadap peningkatan kualitas pelayanan publik yang diberikan oleh para pegawai dan organisasi secara keseluruhan. Unsur sentralisasi akan menjadikan pengaruh pimpinan semakin besar karena dengan adanya kebijakan yang tersentralisasi, maka pengendalian organisasi akan semakin efektif.

Berdasarkan hasil penelitian yang peneliti lakukan diperoleh gambaran bahwa unsur sentralisasi sudah dilaksanakan di dalam organisasi disamping aspek desentralisasi atau distribusi pekerjaan yang disebarkan kepada seluruh pegawai. Hal yang perlu diperhatikan adalah tujuan yang akan dicapai oleh organisasi yaitu merealisasikan visi dan misi organisasi guna memberikan pelayanan yang sebaik-baiknya dan unsur sentralisasi atau sentralisasi adalah merupakan alat untuk menggerakkan organisasi dan menggerakkan seluruh elemen organisasi untuk bergerak secara bersama-sama guna mewujudkan visi dan misi organisasi. Unsur sentralisasi yang dijalankan di dalam organisasi masih perlu ditunjang dengan kemampuan pimpinan untuk membuat kebijakan yang tepat agar proses yang dijalankan di dalam organisasi bisa berjalan secara efektif. 
DECISION: Jurnal Administrasi Publik

Vol. 1 No. 1, Maret 2019

\section{iv. Faktor \\ Lain \\ Mempengaruhi \\ Pelayanan Publik}

Berdasarkan hasil perhitungan statistik diperoleh gambaran bahwa variabel Kualitas Pelayanan Publik pada Kantor Pertanahan Kabupaten Bandung Barat ternyata tidak hanya dipengaruhi oleh variabel restrukturisasi organisasi semata, tetapi juga dipengaruhi oleh faktor-faktor lain sebesar $28,27 \%$. Hal tersebut dimaksudkan bahwa terdapat banyak faktor-faktor lain yang turut meningkatkan Kualitas Pelayanan Publik pada Kantor Pertanahan Kabupaten Bandung Barat diluar variabel restrukturisasi organisasi yang tidak penulis teliti.

\section{Kesimpulan}

Berdasarkan hasil perhitungan koefisien determinasi diperoleh besar pengaruh variable restrukturisasi organisasi terhadap kualitas pelayanan publik pada Kantor Pertanahan Kabupaten Bandung Barat sebesar 71,73\%. Berdasarkan hasil perhitungan tersebut diperoleh hasil bahwa pengaruh variabel restrukturisasi organisasi berpengaruh cukup kuat terhadap kualitas pelayanan publik. Secara Parsial, pengaruh Kompleksitas sebesar $40.16 \%$. Formalitas sebesar $10.32 \%$ dan Sentralisasi sebesar $21.19 \%$ terhadap kualitas pelayanan publik pada Kantor Pertanahan Kabupaten Bandung Barat.

\section{Daftar Pustaka}

Arikunto Suharsimi. 2006. Prosedur Penelitian Suatu Pendekatan Praktik. Jakarta PT. Rineka Cipta. Atmosoeprapto, Kisdartao. 2001. Produktivitas Aktualisasi Budaya Perusahaan Mewujudkan Organisasi yang Efektif dan
Efisien Melalui SDM Berdaya. Jakarta : PT. Elex Media Komputindo

Bennis Warren and Michael Mischa, 1956. Organisasi Abad 21, Reinventing Melalui Reengineering. Penerjemah : Irma Andriani Rachmayanti (1999). Jakarta: PPM dan PT. Pustaka Binama Pressindo.

Berger, Lance A. et. al. 1994. The Change Management Handbook A. Road Map To Corporate Transformation. Chicago : Irwin Professional Publishing.

Braman Lyo, Djohanputm.2001. Restrukturisasi Perusahaan Berbasis Nilai, Strategi Menuju Keunggulan Bersaing. Jakarta : PPM.

Carr, Clay : 1995. Chloe, Chance and Organizational Change, New York : Amacom.

Champy, James. 1995. Reengineering Management, The Mandate For New Leadership, New York : A. Dinsion of Harpek Collins Publishers.

Dessler, Gary. 2004. Management Sumber Daya Manusia. Edisi 9, Alih Bahasa : Eli Tanya, Jakarta : PT. Indek Kelompok Gramedia

Dwiyanto, Agus, (1995), Penilaian Kinerja Organisasi Pelayanan Publik, Fakultas Sosial Politik UGM, Yogyakarta.

Fitzsimmons, James A. and Mona J. Fitzsimmons. 1994. Service Management for Competitive Advantage. New York: McGrawHill, Inc.

Gibson, James L., John M. Ivancevich dan James H. Donnelly, Jr. (1996). Organisasi, Perilaku, Struktur, Proses. (Alih Bahasa 
Nunuk Adiarni), Penerbit Binarupa Aksara, Jakarta.

Gomes, Faustino Cardoso. (2001). Manajemen Sumber Daya Manusia. Yogyakarta: Andi Offset

Goulfian, Prancis J. And James N. Kelly. 1995. Transforming The Organization. New York : McGraw-Hill, inc.

Handoko, T. Hani. 1990. Management. Edisi kedua. Yogyakarta BPFE.

Helien, Fisher. 2004. Layanan Konsumen Dalam Seminggu. Jakarta: Prestasi Pustaka Publisher.

Harits, Benyamin. 2005. Teori Organisasi. Bandung : Insani Press.

Hasibuan, Malayu SP. (2003). Organisasi dan Motivasi Dasar Peningkatan Produktivitas. Bumi Aksara, Jakarta

Hesselbein, Francis dan Rob Johnston. 2005. Learning Change, Strategi Menembus Tantangan Perubahan, Penerjemah Martin Kadaroesman. Jakarta : PT. Elex Media Komputindo.

Husnan, Suad dan Pudjiastuti, Enny. 2004. Dasar-dasar Teori Portofolio dan Analisis Sekuritas. (cetakan ketiga). Yogyakarta. UPP AMP YKPN

Indrawijaya, Adam. 1986. Perilaku Organisasi, Bandung : Penerbit Sinar Baru.

Johaneson, Henry J. et. Al. 1995. Rekayasa Ulang Proses Bisnis, Strategi Terobosan untuk Dominasi Pasar. Alih Bahasa : Agus Maulana. Jakarta Bina Rupa Aksara.

Keban Yeremias. T. 2004. Enam Dimensi Strategis Administrasi
Publik, Konsep, Teori dan Isu. Yogyakarta : Gaya Media.

Kerlinger, Fred. 2004. Asas-Asas Penelitian Behavioral, Penerjemah : Landung R. Simatupang. Gadjah Mada University Press.

Kotler, John P. 1996. Leading Change. Boston USA: Harvard Business School.

LAN, 2003, SANKRI Buku I Prinsipprinsip Penyelenggaraan Negara, Lembaga Administrasi Negara.

LAN, 2003, Penyusunan Standar Pelayanan Publik, Lembaga Administrasi Negara

Lubis \& B. Hari dan Martani Huseini. 1987. Teori Organisasi (Suatu Pendekatan Makro). Jakarta: PAU ilmu-ilmu Sosial Universitas Indonesia.

Miftah Thoha. 1993. Perilaku Organisasi, Konsep Dasar dan Aplikasinya. Jakarta PT. Raja Grifindo Persada.

Nasution, M. N. 2001. Manajemen Mutu Terpadu (Total Quality Management). Bogor : Ghalia Indonesia.

2004. Manajemen Jasa Terpadu. Bogor : Ghalia Indonesia.

Obolensky, Nick. 1996. Practical Business Re-Engineering. Petunjuk Praktis Merekayasa Kembali Bisnis. Alih Bahasa : Soesanto Budidarmo. Jakarta PT. Elex Media Komputindo Kelompok Gramedia.

Pamudji, S. 1997. Praktek Organisasi dan Metode. Jakarta: Pusat Pendidikan Departemen Dalam Negeri.

Parasuraman, A., Zeithaml, V.A., and Berry, L.L (1990), Delivering Quality Service Balancing 
DECISION: Jurnal Administrasi Publik

Vol. 1 No. 1, Maret 2019

Customer Perceptions and Expectation, The Fress Press, New York.

Pasmore, William. A. 1994. Creating Strategic Change, Desingning The Flexible,

Height-Performing Organizafion, New York : John Wiley \& Sons, inc.

Robbins, Stephen P. 1994. Teori Organisasi, Struktur, Desain dan Aplikasi. Edisi Kedelapan. Alih Bahasa : Hadyana Pujaatmaka dan Benyamin Molan. Jakarta : PT. Prenhailindo.

Robbins, Stephen P. 2001. Perilaku Organisasi, Konsep, Kontroversi, Aplikasi Jilid 1, Edisi Kedelapan. Alih Bahasa : Hadyana Pujaatmaka dan Benyamin Molan. Jakarta : PT. Prenhallindo.

Robbins, Stephen P. And Coulter, Mary. 2005. Manajemen, Edisi 7 Jilid 2, Alih Bahasa : T. Hemaya dan Harry Slamet, Jakarta PT. lndeks Kelompok Gramedia.

Robert L. Mathis and John H. Jackson. (2000). Human Resource Management. New York: SouthWestern College Publishing.

Rummler, Geary A. and Alan P. Brace. 1995. Improving Performance. San Francisco : Jossey Bass Publishers.

Sarundajang, 2001, Arus Balik Kekuasaan Pusat ke Daerah, Jakarta. Pustaka Sinar Harapan.

-------------, 2003. Birokrasi dalam

Otonomi Daerah dan Upaya Mengatasi Kegagalannya, Jakarta. Pustaka Sinar Harapan.

Sarwoto. $1983 . \quad$ Dasar-Dasar Organisasi dan Manajemen, Jakarta : Ghalia Indonesia.

Sedarmayanti. 1995. Sumber Daya Manusia dalam Organisasi.
Jakarta : PT. Gramedia Pustaka Utama.

2000. Restrukturisasi dan

Pemberdayaan Organisasi untuk

Menghadapi Dinamika

Perubahan Lingkungan Ditinjau dari Beberapa Aspek Esensial dan Aktual, Bandung : Mandar Maju.

------------, 2001. Sumber Daya Manusia dan Produktivitas Kerja. Bandung: Mandar Maju

Subarsono. AG. 2005. Pelayanan Publik yang Efisien, Responsif, dan NonPartisan. Yogyakarta Gadjah Mada University Press.

Sugiyono, (1994), Metode Penelitian Administrasi, Alfabeta, Bandung.

Suryana Sumantri. (2001). Perilaku Organisasi. Bandung: Universitas Padjadjaran.

Sutarto. 1987. Perubahan Struktur Organisasi. Jakarta: Ghalia Indonesia.

2002. Dasar-Dasar

Organisasi, Cetakan Kedua puluh. Yogyakarta : Gadjah Mada University Press.

Thoha, Miftah. 1995. Perspektif Perilaku Birokrasi. Rajawali. Jakarta

1999. Administrasi
Negara, Masyarakat Madani. Jakarta: Lembaga Administrasi Negara

Tika, Moh. Pabundu. 2000. Metodologi Riset Bisnis, Jakarta : PT. Bumi Aksara

Umar, Husain. 2005. Riset Sumber Daya Manusia Dalam Organisasi. Jakarta : PT. Gramedia Pustaka Utama.

Utomo, Warsito, 1997, Implementasi Desentralisasi dan Otonomi Daerah Tingkat II Masa Orde Baru (Studi Kasus di Dati II Cilacap dan Dati II Kudus) dalam 
JKAP Volume 1 Nomor 2 (Juli 1997) MAP UGM Yogyakarta. (2003). Dinamika Administrasi Publik Analisis Empiris seputar Isu-su Kontemporer dalam Administrasi Publik. Yogyakarta: Pustaka Pelajar.

West, Michael A. 2000. Developing Creativity in Organizations (Membangun Kreativitas dalam organisasi), Alih Bahasa Bern Hidayat. Yogyakarta Penerbit Kanisius.

\section{Dokumen-dokumen}

\begin{tabular}{|c|c|c|}
\hline $\begin{array}{l}\text { akhtiyar } \\
\text { Restrukturis }\end{array}$ & $\begin{array}{l}\text { (2005). } \\
\text { isasi }\end{array}$ & $\begin{array}{c}\text { Pengaruh } \\
\text { Organisasi }\end{array}$ \\
\hline terhadap & Efektivitas & Kerja \\
\hline Pegawai & di Dinas $\mathrm{F}$ & Pendapa \\
\hline Daerah Kot & ta Bandung. & Tesis $p$ \\
\hline Program & Magister & \\
\hline Administras & & Prog \\
\hline Pascasarjan: & & nivers \\
\hline Pasundan B & 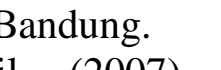 & \\
\hline
\end{tabular}

Sunyoto Fadhil (2007). Pengaruh Restrukturisasi Organisasi terhadap Efektivitas Kerja Pegawai Pada Asisten Administrasi Kabupaten Bandung. Tesis pada Program Magister Ilmu Administrasi Program Pascasarjana Universitas Pasundan Bandung.

Undang-Undang Negara Republik Indonesia Nomor 7 Tahun 1958 tentang Peralihan Tugas Dan Wewenang Agraria

Undang-Undang Negara Republik Indonesia Nomor 22 tahun 1999 tentang Pemerintahan Daerah.

Undang-Undang Negara Republik Indonesia Nomor 25 Tahun 2004 Tentang Pelayanan Publik

Peraturan Pemerintah Republik Indonesia Nomor 41 Tahun 2007 tentang Organisasi Perangkat Daerah. Penyempurnaan dari PP. No. 84 Tahun 2000 dan No. 8 Tahun 2003.

Peraturan Presiden Nomor 10 Tahun 2005 tentang Unit Organisasi dan Tugas Kementerian Negara Republik Indonesia sebagaimana telah beberapa kali diubah, terakhir dengan Keputusan Presiden Republik Indonesia Nomor 15 Tahun 2005

Peraturan Presiden Republik Indonesia Nomor 10 tahun 2006 tentang Badan Pertanahan Nasional

Keputusan Menteri Negara Pemberdayaan Aparatur Negara Nomor 63/KEP/M.PAN/7/2003 Tentang Pedoman Umum Penyelenggaraan Pelayanan Publik.

Keputusan Menteri Negara Pemberdayaan Aparatur Negara Nomor 26/KEP/M.PAN/2/2004 Tentang Petunjuk Teknis Transparansi dan Akuntabilitas Dalam Penyelenggaraan Pelayanan Publik.

Keputusan Kepala Badan Pertanahan Nasional Nomor 4 Tahun 2006 tentang Organisasi dan Tata Kerja Kantor Wilayah Badan Pertanahan Nasional dan Kantor Pertanahan

Direktorat Aparatur Negara, Bappenas, 2004. Peningkatan kualitas pelayanan publik. Jakarta. 